\title{
Short-term incentive schemes for hospital managers
}

\begin{tabular}{|c|c|}
\hline \multicolumn{2}{|c|}{$\begin{array}{l}\text { Authors: } \\
\text { Lucas Malambe } \\
\text { Mark Bussin }{ }^{1}\end{array}$} \\
\hline \multirow{2}{*}{\multicolumn{2}{|c|}{$\begin{array}{l}\text { Affiliations: } \\
{ }^{1} \text { Department of Business } \\
\text { Management, University of } \\
\text { Johannesburg, South Africa }\end{array}$}} \\
\hline & \\
\hline \multicolumn{2}{|c|}{$\begin{array}{l}\text { Correspondence to: } \\
\text { Mark Bussin }\end{array}$} \\
\hline \multicolumn{2}{|c|}{$\begin{array}{l}\text { Email: } \\
\text { drbussin@mweb.co.za }\end{array}$} \\
\hline \multicolumn{2}{|c|}{$\begin{array}{l}\text { Postal address: } \\
\text { PO Box 2334, Saxonwold } \\
2132 \text {, South Africa }\end{array}$} \\
\hline \multicolumn{2}{|c|}{$\begin{array}{l}\text { Dates: } \\
\text { Received: } 27 \text { July } 2012 \\
\text { Accepted: } 03 \text { June } 2013 \\
\text { Published: } 21 \text { Oct. } 2013 \\
\text { Republished: } 06 \text { Feb. } 2014\end{array}$} \\
\hline \multicolumn{2}{|c|}{$\begin{array}{l}\text { How to cite this article: } \\
\text { Malambe, L., \& Bussin, } \\
\text { M. (2013). Short-term } \\
\text { incentive schemes for } \\
\text { hospital managers. SA } \\
\text { Journal of Human Resource } \\
\text { Management/SA Tydskrif vir } \\
\text { Menslikehulpbronbestuur, } \\
\text { 11(1), Art. \#487, } 9 \text { pages. } \\
\text { http://dx.doi.org/10.4102/ } \\
\text { sajhrm.v11i1.487 }\end{array}$} \\
\hline \multicolumn{2}{|c|}{$\begin{array}{l}\text { Note: } \\
\text { Article republished with } \\
\text { updated author information } \\
\text { of Mark Bussin. }\end{array}$} \\
\hline \multicolumn{2}{|c|}{$\begin{array}{l}\text { Copyright: } \\
\text { C) 2013. The Authors. } \\
\text { Licensee: AOSIS } \\
\text { OpenJournals. This work } \\
\text { is licensed under the } \\
\text { Creative Commons } \\
\text { Attribution License. }\end{array}$} \\
\hline \multicolumn{2}{|l|}{ Read online: } \\
\hline 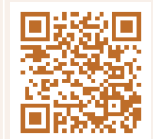 & $\begin{array}{l}\text { Scan this QR } \\
\text { code with your } \\
\text { smart phone or } \\
\text { mobile device } \\
\text { to read online. }\end{array}$ \\
\hline
\end{tabular}

Orientation: Short-term incentives, considered to be an extrinsic motivation, are commonly used to motivate performance. This study explored hospital managers' perceptions of shortterm incentives in maximising performance and retention.

Research purpose: The study explored the experiences, views and perceptions of private hospital managers in South Africa regarding the use of short-term incentives to maximise performance and retention, as well as the applicability of the findings to public hospitals.

Motivation for the study: Whilst there is an established link between performance reward schemes and organisational performance, there is little understanding of the effects of shortterm incentives on the performance and retention of hospital managers within the South African context.

Research design, approach, and method: The study used a qualitative research design: interviews were conducted with a purposive sample of 19 hospital managers, and a thematic content analysis was performed.

Main findings: Short-term incentives may not be the primary motivator for hospital managers, but they do play a critical role in sustaining motivation. Participants indicated that these schemes could also be applicable to public hospitals.

Practical/managerial implications: Hospital managers are inclined to be more motivated by intrinsic than extrinsic factors. However, hospital managers (as middle managers) also seem to be motivated by short-term incentives. A combination of intrinsic and extrinsic motivators should thus be used to maximise performance and retention.

Contribution/value-add: Whilst the study sought to explore hospital managers' perceptions of short-term incentives, it also found that an adequate balance between internal and external motivators is key to implementing an effective short-term incentive scheme.

\section{Introduction}

The South African government intends to implement a National Health Insurance (NHI) system to transform the healthcare funding structure and promote efficiency, equity and access to quality healthcare (Department of Health, 2011). One of the critical drivers of success in the proposed system is the attraction and retention of high quality hospital managers (Department of Health, 2011). The proposed NHI system aims to curb the rising costs of providing healthcare (National Treasury, 2011). Together with perceived declining revenue, the threat of an NHI is resulting in high levels of staff turnover in the healthcare sector (Jones, Havens \& Thompson, 2008). It is asserted that learning and transferring best practices from the private sector in the area of motivating and incentivising managers will aid the attraction and retention of talent in the public sector.

There is a strong, established link between pay for performance and organisational performance (Grigoriadis \& Bussin, 2007; Offstein \& Gnyawali, 2005). This link, however, does not always have a positive impact (Bizjaka, Lemmonb \& Naveen, 2008; Brick, Palmon \& Wald, 2006), especially in healthcare, where costs are considered prohibitively high (McIntyre \& Thiede, 2007). Shortterm incentives have been successfully implemented for top executives and sales personnel across companies in South Africa (Grigoriadis \& Bussin, 2007), but there is no published research on short-term incentives for hospital managers within the context of South Africa. This study sought to assess the perception of private hospital managers regarding the efficacy of short-term incentives in their motivation and retention. It also investigated whether such schemes could be transferred to the public hospital sector.

There is a growing body of evidence proposing that intrinsic motivators dominate employees' decisions to stay with (or leave) a company (Ederhof, 2011; Hlalethoa, 2010; Kerr-Phillips \& Thomas, 2009; Terblanche \& Boshoff, 2010; Van Schalkwyk, Du Toit, Bothma \& Rothmann, 2010). 
Buetow (2008) suggests that for financial incentives to be a powerful motivator, bonuses must reflect both the intrinsic values of the hospital manager, such as competence and autonomy, and the values of the major stakeholders.

Investigating short-term incentives that can inspire hospital managers without compromising healthcare delivery will add value to the theory and practice of employee motivation in the hospital industry. In the long run, hospital managers who are motivated to remain in their jobs for extended periods will use their experience and skills to benefit healthcare.

The study contributes to the body of knowledge regarding motivation of hospital managers. Lessons learnt from the study could be used to stem the loss of experienced managers from the public to the private sector. The study will also add to the scientific knowledge on the application and use of short-term incentives for middle managers.

Retaining the skills of experienced hospital managers is critical if the Department of Health is to achieve its new business strategy, as espoused in the National Health Insurance Policy Paper. Knowing what motivates hospital managers to perform better and stay in their positions for longer periods can be a useful instrument for healthcare policy makers in South Africa.

\section{Literature review}

There are numerous theories that have been designed and used to explain human motivation. One of the most widely known of these is Maslow's (1943) hierarchy of needs. Unlike Maslow's hierarchy of needs, Herzberg's two-factor motivational theory perceives dissatisfaction as playing as crucial a role in demotivating employees as satisfaction plays in inspiring employees to be more productive (Herzberg, Mausner \& Snyderman, 1959). Paleologou, Kontodimopoulos, Stamouli, Aletras and Dimitris (2006) identify four factors referring to intrinsic individual needs and external jobrelated aspects. Table 1 demonstrates how these external and internal motivators link up with job attributes, remuneration, co-workers, and achievement.

The advancement of employee welfare and future needs such as pension and insurance are related to Maslow's need for safety. A good incentive plan must balance the four main roles that incentive plans serve in organisations, namely motivating effort, directing attention, extracting information, and attracting and retaining highly effective employees (Fisher, Sprinkle \& Walker, 2008). Failure to adequately align the extrinsic with the intrinsic motivators risks perpetuating inequalities (Alshamsan, Majeed, Ashworth, Car \& Millett, 2010), creating a culture in which managers demand bonuses simply because they are provided elsewhere (Gross, Elhaynay, Friedman \& Buetow, 2008), or managers engage in opportunistic behaviour to take advantage of the incentive system (Mannion, Marini \& Street, 2008).

Grigoriadis and Bussin (2007, p. 52) define short-term incentives as pay for performance schemes 'where the measurement period is around one year' and payment is 'in cash,' for example, 'profit share, gains share, commission and bonus'.

Table 2 outlines the design elements of short-term incentives designed to measure and shape the delivery of healthcare.

For these key design elements to achieve their objectives, they must be properly monitored to prevent unintended consequences (Ryan, 2010). Table 3 shows seven design features that may greatly enhance the design and effectiveness of short-term incentives in healthcare.

The response of hospital managers to any or a combination of these key design features will be unique to the individual, as these will motivate individuals differently.

The World Health Organisation (WHO) urges all member countries to move towards achieving universal healthcare coverage; that is, a healthcare financing model providing financial risk protection and ensuring equity (WHO, 2005).

TABLE 1: Four components of individual and external needs.

\begin{tabular}{|c|c|c|c|}
\hline Factors & Label & Expression & Manifestation \\
\hline Intrinsic motivators & Job attributes & $\begin{array}{l}\text { Participation in decision-making, creativity and skill } \\
\text { exploitation }\end{array}$ & $\begin{array}{l}\text { Individual's self-needs, generated from internal values that must } \\
\text { be satisfied before true job satisfaction can be experienced }\end{array}$ \\
\hline Extrinsic work-related motivators & Remuneration & Salary and benefits, pension, insurance and bonus & $\begin{array}{l}\text { Generated from external values that must be satisfied before true } \\
\text { job satisfaction can be experienced }\end{array}$ \\
\hline Intrinsic motivators & Co-workers & $\begin{array}{l}\text { Recognition, performance-linked awards and invitations } \\
\text { to contribute in important meetings }\end{array}$ & $\begin{array}{l}\text { Professional relationships with supervisors and colleagues as a } \\
\text { source of satisfaction and potential motivation }\end{array}$ \\
\hline Intrinsic motivators & Achievement & Pride, appreciation, respect and social acceptance & Generated from individual's internal needs \\
\hline
\end{tabular}

Source: adapted from Paleologou, V., Kontodimopoulos, N., Stamouli, A., Aletras, A., \& Niakas, D. (2006). Developing and testing an instrument for identifying performance incentives in the Greek health care sector. BMC Health Services Res, 6, 118-128

TABLE 2: Key design elements of short-term incentive schemes.

\begin{tabular}{lll}
\hline Design element & Common factors & Diverse factors \\
\hline Objectives & Quality healthcare & Volume, equity, patient satisfaction, patient safety and cost-effectiveness \\
Unit of assessment & Top and middle managers & Individual clinicians, clinical teams or larger organisational aggregates \\
Performance measures & Driven by choice of objectives & Process versus outcomes \\
Analysis and interpretation of performance data & $\begin{array}{l}\text { Link between actual performance and measured } \\
\text { performance }\end{array}$ & Vary widely in the sophistication of the data analyses that underpin them \\
Performance standards & Performance criteria & Benchmarks \\
Financial rewards & Size & Predictability \\
\hline
\end{tabular}

Source: adapted from Mehrotra, A., Sorbero, M.E.S., \& Damberg, C.L. (2010). Using the lessons of behavioral aeconomics to design more effective pay-for-performance programs. American Journal of Managed Care, 16(7), 497-503 
TABLE 3: Seven design features to improve pay-for-performance programmes.

\begin{tabular}{lll}
\hline Number & Commonly used design & Suggested improvement \\
\hline 1 & Incentive given as a lump sum & Divide the lump sum into a series of smaller incentive payments \\
2 & Relative thresholds & Use tiered absolute thresholds (e.g., $25 \%, 50 \%, 75 \%$ and $90 \%)$ \\
3 & Long lag time between care and receipt of incentive & Shorten lag time to as short as possible \\
5 & Use of withhold payments & Consider bonus payment or use of deposit contracts \\
7 & Complex, unclear structure of programme (e.g. shared savings programme) & Simplify programme so that uncertainty is minimised \\
\hline
\end{tabular}

Source: adopted from Mehrotra, A., Sorbero, M.E.S., \& Damberg, C.L. (2010). Using the lessons of behavioral economics to design more effective pay-for-performance programs. American Journal of Managed Care, 16(7), 497-503

McIntyre, Goudge, Harris, Nxumalo and Nkosi (2009, p. 726) postulate that $\mathrm{NHI}$ would be 'a single pool of funds comprising allocations from the general tax revenue and mandatory contributions utilised to acquire quality healthcare from recognised providers'. Ensuring that all the key ingredients for the success of NHI are in place will rest on the motivation of public hospital managers and staff (Ataguba \& Akazili, 2010; McIntyre et al., 2009). Motivation is vital for performance management practices in hospital industries that have either achieved universal coverage or are moving towards its achievement (Dambisya, 2007; Peng, Pike \& Roos, 2007).

In the long run, hospital managers who are motivated to stay in their jobs for longer and are motivated to perform will use their experience and skills to benefit healthcare. A review of the literature has revealed that few studies in South Africa have examined the effect of short-term incentives on middle managers. There is no published research focusing on hospital managers and the use of short-term incentives to drive their performance and increase their retention. The present study therefore sought to explore the perceptions, views, feelings and thoughts of private hospital managers to understand the impact of short-term incentives on their performance and retention.

\section{Method}

\section{Research approach}

This study was exploratory and followed a qualitative design to understand the perceptions of hospital managers regarding short-term incentives. The qualitative approach allows the researcher to take an 'insider perspective' to investigate research questions comprehensively, honestly, and in detail (Babbie \& Mouton, 2010). As part of the interpretive paradigm, the qualitative research design involves taking 'people's subjective experiences seriously as the essence of what is real for them (ontology)' and constructing logic and meaning 'by interacting with them and listening carefully to what they tell' researchers (epistemology)' (Terre Blanche, Kelly \& Durrheim, 2008, p. 273).

Terre Blanche et al. (2008) conclude that an in-depth understanding of the respondents' insights can be gained from integrating, linking and matching their points of view to the research questions without losing the context that underpins their perspectives. The present researcher believes that to discover the truth and knowledge is to understand the meaning of the reality that the participants connect to motivation and short-term incentives within the milieu of being a hospital manager.

\section{Research strategy}

The population of the study was private hospital managers. The Hospital Association of South Africa (HASA) maintains a database of all known private hospitals in Southern Africa; this was used as a sampling frame. HASA represents over 95\% of private hospitals in South Africa.

The researcher was employed by the HASA at the time of this study, and had easy access to the hospital managers. This also gave the researcher the advantage of insight into the organisational processes and behaviours in the private hospital industry. After the sampling process, consent to participate in the study was solicited. This was done through a formal letter, followed by a telephone call for confirmation and to set up the interview. In some cases, top management of the hospitals was engaged to give the managers permission to participate in the research.

\section{Sampling}

The HASA database, containing 215 private hospitals and approximately the same number of hospital managers, was used as a sampling frame. Purposive sampling, a type of judgemental sampling, provided the researcher with a sample that was representative of both the bigger, major hospital groups and smaller, independent hospitals. This minimised ecological fallacy, defined by Durrheim (2008, p. 41) as the type of logical error that occurs 'when a researcher investigates one unit of analysis, and then draws conclusions about a different unit of analysis'. Though purposive sampling is suitable in qualitative studies (Onwuegbuzie \& Leech, 2007), there is no widely accepted figure for the sample size (Durrheim, 2008). Nonetheless, Onwuegbuzie and Collins (2007, p. 289) note that the size of the sample in qualitative research should not be so small 'as to make it difficult to achieve data saturation, theoretical saturation, or informational redundancy', or so big as to make it complicated 'to undertake a deep, case-oriented analysis'. The present study researched the perceptions of 19 hospital managers in Gauteng, North West and Mpumalanga, due to proximity to the researcher.

\section{Data collection method}

A qualitative strategy using semi-structured interviews was deemed most suitable to provide an in-depth description of hospital managers' perceptions and experiences, as it is participatory and reduces mistrust between research subjects and researchers (cf. Babbie \& Mouton, 2010). The researcher grouped themes from the responses in order to answer the 
research questions, namely determining the short-term incentives for hospital managers.

Data were collected through semi-structured interviews that consisted of flexible and open-ended questions. The literature review was used to compile the guiding themes and questions for the qualitative study. The interviews were conducted from the middle of May 2011 to the end of July 2011. Taking between 45 and 60 minutes, the interviews took place at the research participants' workplaces. Each interview began with a confirmation of the objectives of the study. Interviewees were then assured of the confidentiality of all data collected.

\section{Recording of data}

The researcher requested and was granted permission to record the interviews, using an electronic recording device to ensure accuracy. The researcher also took notes during the interviews.

\section{Data analyses}

The unordered raw data were transformed into a data set of meaningful themes that could be easily analysed. The analysed data formed patterns of similarities and differences that were further analysed and interpreted against the major constructs and objectives of the study. Johnson and Barach (2008, p. 196) note that the aim of this process is to build up a comprehensive 'representation of the words and actions and hopefully to capture the thoughts behind them'.

\section{Strategies employed to ensure quality data}

The researcher followed the suggestion of Onwuegbuzie and Leech (2007) that the collection and analysis of data be documented meticulously and cautiously to assure reliability. The study provides all the details of the research process, including conceptualisation, sampling, data collection techniques and data analysis processes, to allow the audience to judge the degree to which the research is transferable to other settings.

\section{Reporting}

The findings are presented in tables in an objective manner. To capture the essence of the participants' perceptions,

TABLE 4: What motivates you to perform better?

\begin{tabular}{lll}
\hline Emerging theme & Frequency & $\mathbf{\%}$ \\
\hline Improved results or success & 12 & 63 \\
Financial incentives & 6 & 32 \\
Promotion prospects & 6 & 32 \\
Pressure & 3 & 16 \\
\hline
\end{tabular}

verbatim excerpts from the accounts of the participants are quoted. To ensure participant confidentiality, no reference is made to individual respondents, their locations or the hospitals they manage.

\section{Findings \\ The nature of a short-term incentive scheme for hospital managers}

All of the respondents $(N=19 ; 100 \%)$ indicated that short-term incentive schemes are used in the private hospital industry to motivate hospital managers. All respondents $(N=19 ; 100 \%)$ mentioned that a bonus is the most common short-term incentive scheme being used to motivate hospital managers. The majority of respondents $(N=14 ; 74 \%)$ also mentioned that a variable compensation scheme or a combination of a bonus and a share scheme is also used in motivating hospital managers.

The majority of the respondents $(N=11 ; 58 \%)$ listed a bonus as one of the tools used by their own employers to motivate hospital managers. Most of these respondents defined the bonus as 'calculated as a percentage of basic salary'. Six of the respondents work for a company that uses a combination of shares and cash (as a bonus) $(N=6 ; 32 \%)$. However, on further probing, these shares appear to be redeemable only after a period in excess of one year: 'Though the shares are given to you based on your performance for this financial year, you'll only cash them in in three years time.' The balance of the respondents $(N=2 ; 10 \%)$ declined to be specific, as they considered their own incentives a private matter. They preferred talking in general terms, and continued to participate in the study.

\section{Factors other than short-term incentives that motivate hospital managers}

From responses received, four motivational factors emerged. Table 4 shows that most of the respondents indicated 'results' or 'a desire to succeed' $(N=12 ; 63 \%)$ as what motivates them to work harder.

The need to succeed was defined in a variety of ways; for instance, 'the success of the hospital'; 'bringing the [hospital] to the next level'; and 'leaving [the hospital] a smooth-running place as compared to the initial state'.

From the responses received when participants were asked about the benefits of short-term incentives, the researcher grouped similar comments to formulate themes. Table 5 demonstrates that respondents perceived short-term incentives as a motivational tool to improve clinical governance in

TABLE 5: Emerging themes regarding perceived pay-for-performance benefits.

\begin{tabular}{lll}
\hline Theme & $\boldsymbol{N}$ & Quotation \\
\hline Planning mechanism & 6 & 'Provide a platform for setting up goals for the next period.' \\
Improve clinical governance & 10 & 'Well-incentivised managers make doctors happy, and happy doctors will want to stay within my hospital.' \\
Improve company performance & 6 & 'Ensure company goals are met.' \\
Loyalty & 6 & 'Create a sense of attachment to company.' \\
Recognition & 6 & 'Boost self-esteem.' \\
\hline
\end{tabular}

$N$, number of respondents. 
hospitals $(N=10 ; 53 \%)$, encourage loyalty $(N=6 ; 32 \%)$, improve company performance $(N=6 ; 32 \%)$, improve planning $(N=6 ; 32 \%)$ and boost self-esteem $(N=6 ; 32 \%)$.

Regarding the negative consequences of not implementing pay-for-performance schemes, four themes emerged, as seen in Table 6 . Staff turnover $(N=7 ; 37 \%)$, poor performance $(N=6 ; 32 \%)$ and the demoralisation of workers $(N=4 ; 21 \%)$ were mentioned as the likely consequence of failing to pay a bonus to hospital managers for performance.

\section{Drivers of a short-term incentives policy}

Financial performance $(N=10 ; 53 \%)$ was mentioned most frequently as the major driver of the implementation of a policy of providing short-term incentives for hospital managers. Respondents also mentioned competition $(N=4$; $21 \%)$, talent retention $(N=4 ; 21 \%)$, transformation $(N=4$; $21 \%)$ and clinical governance $(N=4 ; 21 \%)$ as strong drivers of such a policy. Respondents who perceived competition to be the major driver mentioned that 'what happens in the market' is more important than what happens internally in deciding on the use of short-term incentives.

Even so, most of the respondents $(N=8 ; 42 \%)$ were content with the way short-term incentives for hospital managers are administered. Table 7 shows the gaps in the policy and implementation identified by the participants.

The existing gaps point a way to other strategies that the industry could use to improve pay-for-performance schemes.

\section{Short-term incentive measures}

Respondents mentioned clinical governance and quality of healthcare most frequently $(N=13 ; 68 \%)$ as critical measures of pay for performance for hospital managers. Financial performance $(N=9 ; 47 \%)$ and how a manager manages human resources $(N=9 ; 47 \%)$ also emerged as important performance indicators for hospital managers. Patient satisfaction, number of patients, performance of the group as well as management of resident doctors and specialists were also mentioned as components of the measurement criteria.

\section{Applicability of private hospital managers' short-term incentives to the public sector}

As seen in Table 8, 13 respondents $(68 \%)$ indicated that applying short-term incentives in the public sector will motivate hospital managers. Other respondents were either not sure $(N=3 ; 16 \%)$ or disagreed $(N=3 ; 16 \%)$ with this suggestion.

Respondents who were not in favour of implementing payfor-performance schemes in the public sector believe that improving the working conditions in the public sector will be more motivational to hospital managers than paying a bonus.

\section{Discussion \\ Outline of the results}

The main objective of the study was to explore the perceptions of hospital managers regarding short-term incentives. The respondents showed an acute awareness of pay-forperformance schemes being used to motivate hospital managers. Even though intrinsic factors are key motivators of hospital managers, the absence of extrinsic motivators such as a bonus is demoralising, and may lead to poor performance or cause hospital managers to leave for greener pastures. These findings confirm Herzberg's theory that dissatisfaction plays as crucial a role in demotivating employees as satisfaction plays in inspiring them (Herzberg et al., 1959).

TABLE 6: Emerging themes of likely consequences of not using short-term incentives.

\begin{tabular}{lll}
\hline Theme & $N$ & Quotation \\
\hline Poor performance & 6 & 'They must have the carrot, or the results will be poor.' \\
Staff turnover & 7 & 'The competition is likely to use that to its advantage.' \\
No consequences & 6 & 'Pay a good basic salary, ensure you pay at the top of the quartile, and there's no need for incentives.' \\
Demoralisation & 4 & 'A lot of demoralised managers.' \\
\hline
\end{tabular}

Note: Six respondents $(N=6 ; 32 \%)$ thought that short-term incentives play no part in motivating hospital managers if a company pays a competitive basic salary.

$N$, number of respondents.

TABLE 7: Gaps in the current pay-for-performance by theme.

\begin{tabular}{|c|c|}
\hline Existing gaps & Responses to the question: What are the gaps in the current pay-for-performance scheme? \\
\hline \multirow[t]{5}{*}{ Lack of flexibility } & 'The structure is too rigid. You can motivate more managers by using other forms of motivation like extra leave days.' \\
\hline & 'Remove the rigidity in the implementation of incentives.' \\
\hline & 'Now you have to operate within the structure - no flexibility. We lose good people because of this structure.' \\
\hline & 'Too much standardisation - the bosses don't see managers as individuals. You become a number, and I want to be different.' \\
\hline & 'How can I perform when our policies must look the same?' \\
\hline Unfair review measurement criteria & 'I become frustrated when I'm measured on deliverables that are out of my control.' \\
\hline Not aware of any & 'Difficult to say, because I'm not at the top and looking at the bigger picture.' \\
\hline Pay that is not competitive & 'Restructuring the basic salary may improve morale.' \\
\hline Poor alignment with cash-flow management & $\begin{array}{l}\text { 'I'd make the measurement period shorter than a year. From a cash-flow perspective, it should be more meaningful if it's after } \\
\text { every six months.' }\end{array}$ \\
\hline \multirow[t]{2}{*}{ The whole structure requires reviewing } & $\begin{array}{l}\text { 'The structure emphasises the performance of the group ... the result is that outstanding performers are rewarded the same as } \\
\text { non-performers.' }\end{array}$ \\
\hline & 'Differentiate group from hospital performance.' \\
\hline
\end{tabular}


A bonus, calculated as a percentage of basic salary, emerged as the most common short-term incentive used to motivate hospital managers. Some hospitals use a combination of a bonus and shares. Even though the shares can only be redeemed after a period in excess of a year, the fact that these are awarded as a result of a manager's performance in a financial year is in line with Grigoriadis and Bussin's (2007) definition of a short-term incentive.

The respondents perceived short-term incentives for hospital managers as a tool to improve clinical governance, planning, loyalty, performance and managers' self-esteem. These benefits support Buetow's (2008) belief that motivation in healthcare is largely intrinsic and should reflect the values of the managers' need for professional fitness and independence. Likewise, the perceptions of the hospital managers show that governance structures are successful in aligning pay-for-performance incentives with the interests of major stakeholders.

As seen in Table 9, improving clinical governance (as a benefit to the hospital), the desire to see better results (as a motivation for the manager), as well as high staff turnover (as the likely consequence of not implementing the schemes), were all rated highly by the participants.

These findings suggest that using short-term incentives to enhance both individual and organisational performance must provide a balance between internal and external motivators. Building on Maslow's (1943) hierarchy of needs and Herzberg et al.'s (1959) theory of motivation, Paleologou et al. (2006) also note that job satisfaction and performance respond to both inherent individual needs and external jobrelated factors. Hlalethoa (2010) also confirms that there is an inescapable connection between extrinsic and intrinsic factors motivating an employee's decision to perform and remain with or leave the organisation.

In a study by Bussin and Huysamen (2004) of remuneration policy drivers, the majority of the respondents listed boosting company financial performance as the major driver of a policy regarding short-term incentives. They also mentioned competition from other hospitals, talent retention, transformation, clinical governance and quality of healthcare as other strong policy drivers. That clinical governance and the quality of healthcare are ranked so highly is indicative that the drivers are linked to areas of implementation. There is no indication that such schemes are used as a control tool, as reported by McDonald, Harrison and Checkland (2008). Implementing short-term incentives as a response to competition and sagging clinical governance corresponds with the competency-based performance systems outlined by Calhoun et al. (2008).

Most of the respondents were satisfied with the way the shortterm incentives for hospital managers are administered in their hospitals, and would not choose to improve any aspects thereof. Respondents who perceived gaps in the short-term incentive schemes identified areas of improvement that tied in with what the managers perceived as the benefits of using short-term incentives. These gaps can also be seen as due to a desire for the managers to be measured on factors within their control. For instance, one respondent expressed the frustration that ensues when 'measured on deliverables that are out of my control'. Another bemoaned the impact of a competitor building a new hospital nearby: '[A new hospital in the area] will affect me directly, but I'm still expected to perform better than before there was any competition.'

TABLE 8: Extrapolation of results from the private to the public hospital sector.

\begin{tabular}{ll}
\hline Respondent's answer & Statements provided in response to the question: Do you think applying these schemes in the public sector can motivate public hospital managers to \\
perform better? & 'If resources are available.' \\
'It will minimise the "I don't care" attitude.' \\
'It will make somebody work a bit harder.' \\
'If it is strictly controlled and done like our group.' \\
'Many managers in the public sector may think "even if I do well, nobody cares". Incentivising them may change this attitude.' \\
'Everybody is struggling to keep their staff, and incentives may work to keep the best in the public sector.' \\
'It must be linked to skills and good performance rating systems to ensure it works.' \\
'I've worked in the public sector, and I don't see it working without finding out what motivates people serving in the public sector.' \\
'If you can't see your progress as a manager in the public sector, you'll not be motivated, regardless of your bonus.' \\
'Unless the manager can see progress and a chance for growth, no bonus will motivate him.' \\
'The way to motivate them is to give them a good basic salary, better working conditions, and growth potential.' \\
'The public sector has other problems such as issues of control and delegation that goes [sic] beyond the compensation.' \\
'But there are many other problems that the public hospitals must deal with before establishing incentives for managers. They still need to worry about \\
putting the right people in the right jobs.'
\end{tabular}

TABLE 9: Perceived benefits of short-term incentives for the hospital.

\begin{tabular}{llll}
\hline Perceived benefits for the hospital & C & Motivational factors for the hospital manager & Likely consequences of not using schemes \\
\hline Improved clinical governance $\dagger$ & 12 & Better results $\dagger$ & Staff turnover $\dagger$ \\
Improved company performance & 9 & Financial incentives & Poor performance \\
Improved loyalty and recognition & 9 & Promotional prospects & No consequences \\
Planning mechanism & 5 & Pressure & Demoralisation \\
\hline
\end{tabular}

C, counts; $N$, number of respondents.

$\dagger$, highly ranked. 
Respondents who thought that short-term incentives would not work in public sector deliberated that hospital managers anywhere would respond more to intrinsic than extrinsic motivators. They mentioned that an opportunity to grow in the profession should be enough to motivate managers. A good basic salary and a bonus would motivate public hospital managers just as better working conditions, growth potential and hiring the 'right people in the right jobs' would. Like those in the private sector, public hospital managers must be expected to show measurable outcomes and efficiency in practising evidence-based healthcare delivery if they are to be incentivised for their competencies and efforts.

\section{Practical implications}

Based on the findings of the study, the researcher developed a framework for short-term incentives in the public hospital sector. Figure 1 indicates that key drivers, design factors and performance measures must be geared to ensure that health conditions, life expectancy, mortality and the general wellbeing of society are improved. It is therefore imperative to develop a deeper understanding of these factors and learn how they may contribute to a public hospital's ability to deliver quality healthcare. The framework also suggests that balancing intrinsic and extrinsic motivators must be at the centre of a short-term incentive scheme to address all the aspects that motivate hospital managers.

The findings show that the majority of the respondents believed that improving public hospital performance and clinical governance must be the major policy drivers. The respondents cited hospital performance and enhancing clinical governance as critical factors in improving excellence in the public hospital sector. As the centrepiece of the NHI is improving the quality of the country's health system, motivated public hospital managers are crucial to its success. The respondents also suggested that improving the working conditions of the managers in the public and private sectors, ensuring career growth prospects and incorporating their desire to succeed will enhance both the performance and esteem of public hospital managers. In turn, this will have a positive impact on the healthcare delivery outcomes of public hospitals.

Furthermore, ensuring a competitive basic salary structure and an adequate bonus as a percentage of annual salary will motivate public hospital managers. As noted by Dambisya (2007) and found in the present study, the motivation of hospital managers may be the missing link in making public hospitals centres of excellence, as envisaged by the NHI. The establishment of short-term incentives for public hospitals will be successful, respondents believed, if performance is adequately linked to measurable outcomes and competencies and is closely monitored. For the evidencebased measurement criteria to be perceived as fair and within the control of the manager, the framework must incorporate regular monitoring and evaluation. This means that the framework must be strictly tied to the performance contract targets agreed upon between top officials and the hospital manager. The key elements of the framework would need to be designed in such a way that they enhance health conditions, life expectancy and the general wellbeing of society, whilst lowering morbidity and mortality, as envisaged by the NHI (Department of Health, 2011).

\section{Limitations of the study}

The focus of the study was to explore the use of short-term incentive schemes in the private hospital industry. The study's approach was qualitative, and relied on the subjectivity of the respondents. There is no conclusive evidence that these perceptions of private hospital managers would be the same as those of public hospital managers. This study provides an insider perspective on the use of short-term incentives in a

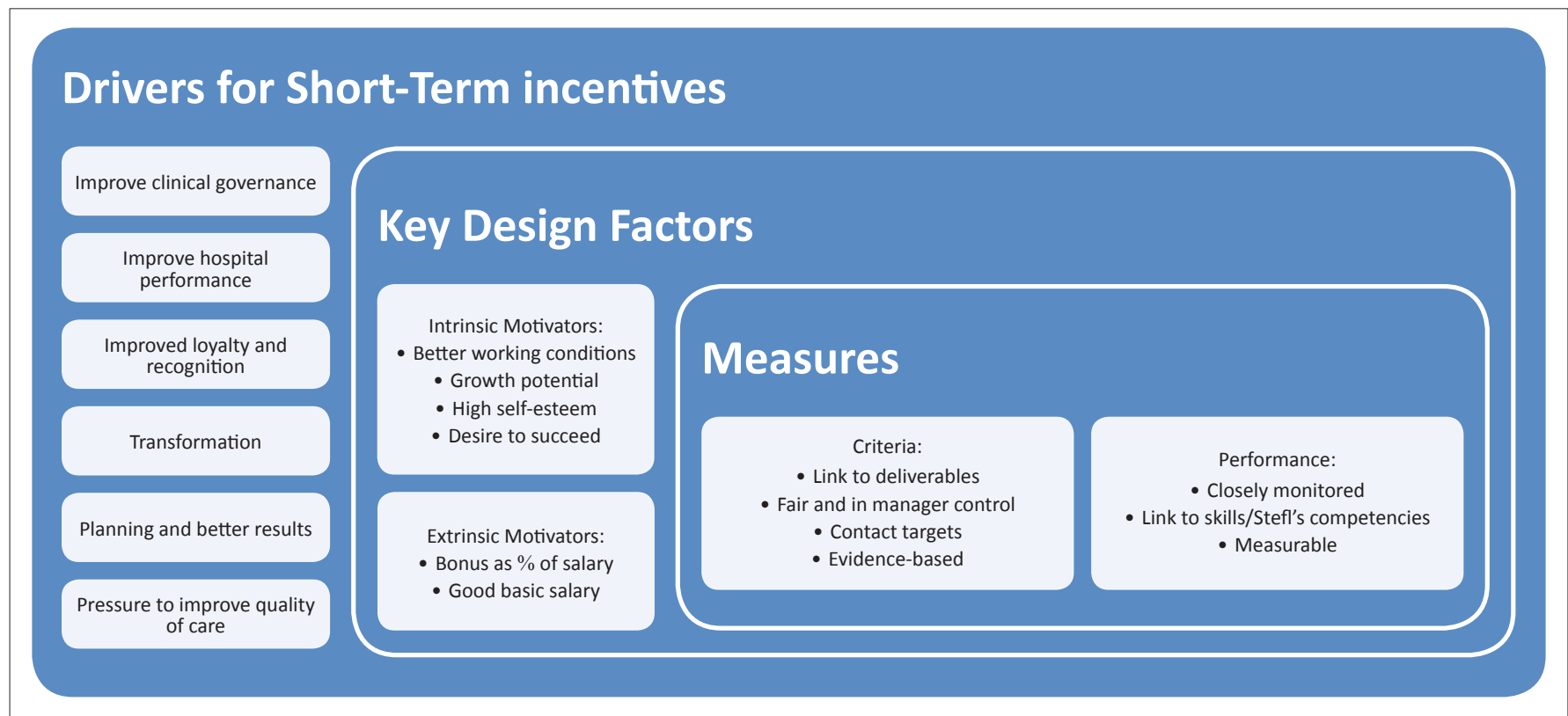

FIGURE 1: Framework for the incentives of public hospital managers. 
specific setting, rather than an analysis of the general practice of using short-term incentive schemes. Testing the effects of short-term incentives using a quantitative technique could determine the reputation and attractiveness of these schemes across the entire healthcare sector.

\section{Recommendations}

Focusing on the private sector hospital manager responses, this study infers a value-add to the public sector hospital management of incentives. Further studies on the insider perspectives of public hospital managers regarding the implementation of short-term incentives could be the key in motivating managers to improve the quality of healthcare and also in retaining scarce skills in public hospitals, especially now that policymakers are considering implementing an NHI system.

Important areas here will be improving clinical governance, the quality of healthcare, as well as relationships with Human Resources and other stakeholders, such as patients and independent doctors and specialists working at the hospitals. It emerged from the study that there are two parallel shortterm incentive systems, namely a bonus and a combination of a bonus and share options. A longitudinal study could be useful in establishing the efficacy of the different types of short-term incentives for hospital managers.

\section{Conclusion}

This study was conducted at a time when South Africa was reviewing the funding structure of the entire health sector and suggesting an NHI system as a strategy to improve access to quality healthcare. Short-term incentives and healthcare in the country that can inspire managers to perform better and stay longer in their jobs will contribute to the success of the health system. The research confirmed that providing a proper balance between intrinsic and extrinsic motivators is the key to designing a performance management framework to keep hospital managers motivated.

The findings can also be used to cultivate strategies and policies designed to recruit, motivate and retain hospital managers in public hospitals. The study provides a convincing case for both the private and the public sector to review its current reward and incentive strategy in a way that would prevent managers from moving to the private sector. Retaining skills in the public sector is critical for the Department of Health to achieve its new business strategy, as espoused in the National Health Insurance Policy Paper.

The findings of the study suggest that the framework used to motivate private hospital managers will also be effective in public hospitals. Similarly to executives and sales staff, hospital managers (as middle managers) are positively motivated by short-term incentive schemes. Bonus payments may not be the major motivator of hospital managers, but they are key in ensuring that managers stay motivated and in their jobs. Hospitals' boards of directors and top management must establish frameworks to guide the process of designing and implementing a motivation strategy for hospital managers. Pay for performance motivates hospital managers to improve company results and stay in their jobs. It also makes middle managers feel wanted. Furthermore, reflecting on the managers' need for competence and autonomy, shortterm incentives can be used as a planning tool to ensure effective performance management processes.

It is recommended that top managers consider reviewing short-term incentive frameworks to better respond to what is happening at the hospital (business unit), rather than at the organisation or group level, as hospital managers are motivated more by areas within their spheres of control. Reviewing the implementation of short-term incentives must also take into consideration other gaps identified by the respondents, such as making the framework more flexible (customised), improving basic salary and aligning performance measurement criteria to the business unit's cash flow.

\section{Acknowledgements Competing interest}

The authors declare that they have no financial or personal relationship(s) that may have inappropriately influenced them in writing this article.

\section{Authors' contributions}

L.M. (University of Johannesburg) conducted this research in partial fulfilment of a MCom degree. M.B. (University of Johannesburg) was the supervisor. Both L.M. and M.B. wrote the article.

\section{References}

Alshamsan, R., Majeed, A., Ashworth, M., Car, J., \& Millett, C. (2010). Impact of pay for performance on inequalities in health care: Systematic review. Journal of Health Service Research Policy, 15, 178-184. http://dx.doi.org/10.1258/jhsrp.2010.009113, PMid:20555042

Ataguba, J.E., \& Akazili, J. (2010). Health care financing in South Africa: Moving towards universal coverage. Continuing Medical Education, 28(2), 74-78.

Babbie, E., \& Mouton, J. (2010). The practice of social research. (South African edn.). Cape Town: Oxford University Press, Southern Africa.

Bizjaka, J.M., Lemmonb, M.L., \& Naveen, L. (2008). Does the use of peer groups contribute to higher pay and less efficient compensation? Journal of Financial Economics, 90(2), 152-168. http://dx.doi.org/10.1016/j.jfineco.2007.08.007

Brick, I.E., Palmon, O., \& Wald, J.K. (2006). CEO compensation, director compensation, and firm performance: Evidence of cronyism? Journal of Corporate Finance, 12(3), 403-423. http://dx.doi.org/10.1016/j.jcorpfin.2005.08.005

Buetow, S. (2008). Pay-for-performance in New Zealand primary health care. Journal of Health Organization and Management, 22(1), 36-47. http://dx.doi.org/10.1108/ 14777260810862399, PMid:18488518

Bussin. M.H.R., \& Huysamen, D. (2004). Factors driving change to remuneration policy and outcomes. SA Journal of Human Resource Management, 2(2), 45-54. http:// dx.doi.org/10.4102/sajhrm.v2i2.40

Calhoun, J.G., Dollett, L., Sinioris, M.E., Wainio, J.E., Butler, P.D., Griffith, J.R., et al (2008). Development of an interprofessional competency model for healthcare leadership. Journal of Healthcare Management, 53(6), 375-391. PMid:19070333

Dambisya, Y.M. (2007). Review of non-financial incentives for Health Worker Retention in East and Southern Africa. Harare: Regional Network for Equity in Health in Southern Africa. PMid:18232269

Department of Health. (2011). National Health Insurance: Policy paper. Pretoria: Republic of South Africa.

Durrheim, K. (2008). Quantitative research analysis. In M. Terre Blanche, K. Durrheim, $\&$ D. Painter (Eds.), Research in practice: Applied methods for social sciences, (2nd edn.), (p. 41). Cape Town: UCT Press.

Ederhof, M. (2011). Incentive compensation and promotion-based incentives of midlevel managers: Evidence from a multinational corporation. Accounting Review, 86(1), 131-153. http://dx.doi.org/10.2308/accr.00000007 
Fisher, J.G., Sprinkle, G.B., \& Walker, L.L. (2008). Incentive compensation: Bridging theory and practice. Journal of Corporate Accounting and Finance, 19(3), 35-40. http:// and practice. Journal of Corporat
dx.doi.org/10.1002/jcaf.20383

Grigoriadis, C., \& Bussin, M. (2007). Current practice with regard to short-term incentive schemes for middle managers. SA Journal of Human Resource Management, 5(1), $45-53$.

Gross, R., Elhaynay, A., Friedman, N., \& Buetow, S. (2008). Pay-for-performance programs in Israeli sick funds. Journal of Health Organization and Management, 22(1), 23-35. http://dx.doi.org/10.1108/14777260810862380, PMid:18488517

Herzberg, F., Mausner, B., \& Snyderman, B. (1959). The Motivation to Work. New York: Wiley.

Hlalethoa, J.J.R. (2010). Reward strategy as a staff retention tool at the financial services board. Unpublished dissertation, University of Johannesburg, South Africa.

Jones, C.B., Havens, D.S., \& Thompson, PA. (2008). Chief Nursing Officer Retention and Turnover: A Crisis Brewing? Results of a National Survey. Journal of Healthcare Management, 53(2), 89-106. PMid:18421994

Johnson, J.K., \& Barach, P. (2008). The role of qualitative methods in designing health care organizations. Environment and Behavior, 40, 191-204. http://dx.doi.org/ $10.1177 / 0013916507311547$

Kerr-Phillips, B., \& Thomas, A. (2009). Macro and micro challenges for talent retention in South Africa. SA Journal of Human Resource Management, 7(1), 82-92.

Mannion, R. Marini, G., \& Street, A. (2008). Implementing payment by results in the English NHS: Changing incentives and the role of information. Journal of Health Organization and Management, 22(1), 79-88. http://dx.doi.org/10.1108/ 14777260810862425, PMid:18488521

Maslow, A.H. (1943). A theory of human motivation. Psychological Review, 50(4), 370-96. http://dx.doi.org/10.1037/h0054346

McDonald, R., Harrison, S., \& Checkland, K. (2008). Incentives and control in primary health care: Findings from English pay-for-performance case studies. Journal of Health Organization and Management, 22(1), 48-62. http://dx.doi.org/10.1108/ 14777260810862407, PMid:18488519

McIntyre, D., Goudge, J., Harris, B., Nxumalo, N., \& Nkosi, M. (2009). Prerequisites for National Health Insurance in South Africa: Results of a national household survey South African Medical Journal, 99(10), 725-729. PMid:20128271

McIntyre, D., \& Thiede, M. (2007). Healthcare Financing and Expenditure (Electronic version). South African Health Review. Retrieved August 13, 2010, from http:// www.hst.org.za/uploads/files/chap3_07.pdf
Mehrotra, A., Sorbero, M.E.S., \& Damberg, C.L. (2010). Using the lessons of behavioral economics to design more effective pay-for-performance programs. American Journal of Managed Care, 16(7), 497-503. PMid:20645665

National Treasury. (2011). Medium term budget policy statement. (Electronic version). Retrieved August 13, 2010, from http://www.treasury.gov.za/documents/mtbps/ 2011/mtbps/MTBPS\%202011\%20Full\%20Document.pdf

Offstein, E.H., \& Gnyawali, D.R. (2005). CEO compensation and firm competitive behavior: Empirical evidence from the U.S. pharmaceutical industry. Journal of Engineering and Technology Management, 22(3), 201-225. http://dx.doi.org/ 10.1016/j.jengtecman.2005.06.004

Onwuegbuzie, A.J., \& Collins, K.M.T. (2007). A typology of mixed methods sampling designs in social science research. Qualitative Report, 12, 281-316. Retrieve April 24, 2011, from http://www.nova.edu/ssss/QR/QR12-2/onwuegbuzie2.pdf

Onwuegbuzie, A.J., \& Leech, N.L. (2007). Sampling designs in qualitative research: Making the sampling process more public. The Qualitative Report, 12, 238-254.

Paleologou, V., Kontodimopoulos, N., Stamouli, A., Aletras, A., \& Niakas, D. (2006). Developing and testing an instrument for identifying performance incentives in the Greek health care sector. BMC Health Services Res, 6, 118-128. http://dx.doi. org/10.1186/1472-6963-6-118, PMid:16970823, PMCid:PMC1578561

Peng, T.A., Pike, S., \& Roos, G. (2007). Intellectual capital and performance indicators: Taiwanese healthcare sector. Journal of Intellectual Capital, 8(3), 538-556. http:// dx.doi.org/10.1108/14691930710774902

Ryan, A.M. (2010). Has pay-for-performance decreased access for minority patients? Health Services Research, 45(1), 6-23. http://dx.doi.org/10.1111/j.1475-6773. 2009.01050.x, PMid:19840137, PMCid:PMC2813434

Terblanche, N.S., \& Boshoff, C. (2010). Quality, value, satisfaction and loyalty amongst race groups: A study of customers in the South African fast food industry. South African Journal of Business Management, 41(1), 1-10.

Terre Blanche, M., Kelly, K., \& Durrheim, K. (2008). Why qualitative research? In M. Terre Blanche, K. Durrheim, \& D. Painter (Eds.), Research in practice: Applied methods for social sciences, (2nd edn.), (p. 273). Cape Town: UCT Press.

Van Schalkwyk, S., Du Toit, D.H., Bothma, A.S., \& Rothmann, S. (2010). Job insecurity, leadership empowerment behaviour, employee engagement and intention to leave in a petrochemical laboratory. SA Journal of Human Resource Management, $8(1), 1-7$.

World Health Organisation (WHO). (2005). World Health Assembly Resolution 58.33. Geneva: World Health Organization (Electronic version). Retrieved October 15, 2011, from http://wwwwhoint/gb/ebwha/pdf files/WHA58/WHA58 33-enpdf 